Article

\title{
Effect of Thermal Processing on Physico-Chemical and Antioxidant Properties in Mulberry Silkworm (Bombyx mori L.) Powder
}

\author{
Artorn Anuduang ${ }^{1,2}$, Yuet Ying Loo ${ }^{1, *}$, Somchai Jomduang ${ }^{2,3}$, Seng Joe Lim ${ }^{1}$ (D) \\ and Wan Aida Wan Mustapha ${ }^{1, *}$ \\ 1 Department of Food Sciences, Faculty of Science and Technology, Universiti Kebangsaan Malaysia, \\ UKM Bangi 43600, Malaysia; a.anuduang@gmail.com (A.A.); joe@ukm.edu.my (S.J.L.) \\ 2 Division of Food Science and Technology, Faculty of Agro-Industry, Chiang Mai University, \\ Chiang Mai 50100, Thailand; somchai.j@cmu.ac.th \\ 3 Biosafe Holding Partnership Limited, 353 Moo 9, Tambol Sanklang, Sanpatong District, \\ Chiang Mai 50120, Thailand \\ * Correspondence: wanaidawm@ukm.edu.my (W.A.W.M.); yuetying88@gmail.com (Y.Y.L.); \\ Tel.: +603-8921-3870 (ext. 5963) (W.A.W.M.)
}

Received: 26 April 2020; Accepted: 30 June 2020; Published: 3 July 2020

\begin{abstract}
The mulberry silkworm (Bombyx mori L.) is a common edible insect in many countries. However, the impact of thermal processing, especially regarding Thai silkworm powder, is poorly known. We, therefore, determined the optimum time for treatment in hot water and subsequent drying temperatures in the production of silkworm powder. The silkworms exposed to $90^{\circ} \mathrm{C}$ water for $0,5,10$, 15, and 20 min showed values of Total Phenolic Compounds (TPCs), 2,2-Diphenyl-1-picrylhydrazyl free radical scavenging (DPPH) assay, 2,2'-Azino-bis(3-ethylbenzothiazoline-6-sulfonic acid (ABTS) assay, and Ferric Reducing Antioxidant Power (FRAP) assay that were significantly $(p<0.05)$ higher at the 5 min exposure time compared with the other times. The reduction of microorganisms based on $\log$ CFU/g counts was $\geq 3 \log$ CFU/g (99\%) at the 5 min treatment. To determine the optimum drying temperature, the silkworms exposed to $90{ }^{\circ} \mathrm{C}$ water for 5 min were subjected to a hot-air dryer at $80,100,120$, and $140{ }^{\circ} \mathrm{C}$. The TPC value was the highest $(p<0.05)$ at $80^{\circ} \mathrm{C}$. The silkworm powder possessed significantly $(p<0.05)$ higher DPPH, ABTS radical scavenging ability, and ferric ion reducing capability (FRAP assay) at $80{ }^{\circ} \mathrm{C}$ compared with other drying temperatures. This study indicates that shorter exposure times to hot water and a low drying temperature preserve the antioxidant activities. High antioxidant activities (in addition to its known protein and fat content) suggest that silkworms and silkworm powder can make a valuable contribution to human health.
\end{abstract}

Keywords: silkworm; edible insects; thermal processing; antioxidant activities; silkworm powder

\section{Introduction}

The custom of consuming insects as a food source (entomophagy) has been widely practiced by many people from all around the world for thousands of years [1]. Global population growth has led to the increase of food consumption, especially protein. Due to the high protein content, short life cycle, and rapid growth cycle, edible insects may serve as an alternative source of protein for humans, as suggested by Meyer-Rochow [2]. Food security is seen as one of the major global concerns, and therefore, the benefits of edible insect have been re-evaluated, as insects are rich in protein, fats, minerals, and essential vitamins, and contain low amount of carbohydrates. Moreover, insects are abundant and easily bred in large quantities [3]. The mulberry silkworm (Bombyx mori L.) is an edible insect that has been bred for a long time and can be produced throughout the year. 
Silkworms produce silk from plant proteins. In the sericulture industry, the after-silking silkworms are the main by-product and have become a popular food among the 194 species of edible insects in Thailand. In many Asian countries, silkworm has been utilized as food, medicine, and animal feed due to its nutritional profile [4]. Meyer-Rochow [5] mentioned that the larvae, pupae, and adults of B. mori could serve as medicine to treat wounds, sore throats, fever, bleeding, brain hemorrhage, hemorrhoids, and others. Besides phenolic compounds, silkworms also exhibit antioxidant activity [6]. Studies revealed that some pigments found on the yellow Nangnoi silk (Thai silk) are associated with the presence of carotenoids and flavonoids [7,8]. The phenolic compounds are well-known for antioxidant activity as well as some biological functions such as anti-hypertensive [9], antiviral [10], antioxidant [11], antibacterial, and anti-inflammatory activities [12]. Dutta et al. [13] reported that the antioxidant potential of the edible insect Vespa affinis L. could mediate its therapeutic activities in oxidative stress-associated health disorders. Dutta et al. [14] also suggested that the antioxidant potential of the edible insect, Brachytrupes orientalis extract in hydro-alcoholic (AEBO) has a significant role against cellular oxidative impairment.

Silkworm powder, also known as pury, is reported to have a high content of nutrients and tends to be an alternative functional food [15]. The yellowish silkworm powder was reported to possess a high content of nutrients such as protein, essential amino acids, polyunsaturated fatty acid, carbohydrates, vitamins, and minerals. Suk et al. [16] reported that the incorporation of silkworm powder in wheat flour noodles could reduce postprandial glucose response and act as a potential carbohydrate staple food for glycemic control. Park et al. [17] suggested that silkworm powder could be an alternative additive for meat products, as it improved the meat product's physicochemical properties such as protein, fat, and ash contents. Biró et al. [18] concluded that the addition of silkworm powder in buckwheat pasta could increase its nutritional value.

A thermal process is usually employed in the food industry to reduce microbial activity and prolong the shelf life of silkworm products [19]. In addition, thermal processing of food has resulted in physical or chemical changes [20] to ensure the quality standards of food products. Baek et al. [21] stated that hot air drying and oven broiling methods gave the highest score in sensory evaluation in terms of the hardness, crispiness, and aroma in processed mealworm larvae. Meanwhile, Jensen et al. [22] reported that different processing methods were available to alter the taste, aroma, and texture of the insects. In this study, silkworm was processed into a yellowish powder by treatment in hot water, dried, and ground. Thermal processing may destroy some of the bioactive compounds and affect the antioxidant activity in food [23]. Norafida and Aminah [24] revealed that heat treatments (blanching, steaming, or boiling) changed the quality of food products such as texture, taste, color, and nutritional content. Hence, this study aimed to determine the optimal times for treatment in hot water and subsequent drying in the production of silkworm powder.

\section{Materials and Methods}

\subsection{Sample Preparation}

Fresh after-silking silkworms (FASSs) were collected from Natural Thai Golden Silk Ltd. (skincare manufacturing industry, Payao Province, Thailand). Fifth instar silkworms are used to produce silk sheets in the process of developing a skincare product. The silkworms are collected and disposed of as waste after silking. Thus, FASS was chosen in this study to transform the waste into a value-added product. The samples were transferred immediately to the laboratory in the Faculty of Agro-Industry, Chiang Mai University under cold conditions. The silkworm samples were then kept at $-18^{\circ} \mathrm{C}$ until further use. 


\subsection{Thermal Processing}

\subsubsection{Hot Water Treatment (Pre-Treatment of Silkworms)}

A total of $4 \mathrm{~kg}$ of frozen FASS was used in this study. FASSs were exposed to $90{ }^{\circ} \mathrm{C}$ water (ratio of 1:2) for $5,10,15$, and $20 \mathrm{~min}$. The treatment time started when the water temperature reached the desired temperature $\left(90^{\circ} \mathrm{C}\right)$. After each treatment time, the samples were blotted with tissue paper to remove the excess water on the surface of silkworms. The silkworm samples were further analyzed for their physicochemical properties and antioxidant activities. The experiments were carried out in triplicate.

\subsubsection{Drying Process}

The silkworms that were exposed to $90^{\circ} \mathrm{C}$ water for 5 min were then dried. The treated FASS was centrifuged at $1500 \times g$ rpm for $1 \mathrm{~min}$ to remove the excess water from the silkworm. FASS was dried in a hot-air dryer (Kluynamthai, Bangkok, Thailand) at four different temperatures $(80,100,110$, and $120^{\circ} \mathrm{C}$ ). The moisture content of the sample was measured every $30 \mathrm{~min}$ by recording the weight. Weight changes in the sample were used to calculate the moisture content of the sample. The drying process ended when less than $15 \%$ of moisture content was achieved for each drying temperature. The dried silkworms were ground into powder using a blender at 25,000 rpm (Nanotech, Beijing, China) and filtered using a $1.0 \mathrm{~mm}$ mesh sieve to obtain fine silkworm powder. The powder was then further analyzed for its physicochemical properties and antioxidant activities.

\subsection{Physicochemical Properties}

The color, size, and weight of the silkworm were determined in this study. The surface color of silkworms was measured using a Hunter Lab colorimeter (model Color Quest XE, Reston, VA, USA). The color scale gave the measurement of color $\left(\mathrm{L}^{*}, \mathrm{a}^{*}\right.$, and $\left.\mathrm{b}^{*}\right)$ in units of approximate visual uniformity throughout the solid color. $L^{*}$ value determined lightness, where the score of 100 showed perfect white color and 0 for black color. Moreover, $a^{*}$ measured the redness when positive, whereas $b^{*}$ measured the yellowness when positive. The length and width of silkworms were measured by a Vernier caliper. The weight of the silkworm was recorded, and the average weight was calculated.

\subsection{Proximate Analysis}

Moisture content (method 934.01), ash (method 923.03), and total fat (method 991.36) were analyzed using the protocols of the Association of the Official Analytical Chemists (AOAC). Protein content $(\mathrm{N} \times 6.25)$ was examined using the AOAC Kjeldahl method (984.13). Carbohydrate was obtained by the formula of 100 - (the sum of moisture, protein, fat, and ash).

\subsection{Total Microorganism}

The total microorganisms in the silkworm were determined using the aerobic plate count method, as described in the FDA's Bacteriological Analytical Manual (Chapter 3) [25]. The silkworms (10 g) were pre-enriched in tryptic soy broth ( $90 \mathrm{~mL}$; Merck, Darmstadt, Germany) in a 1:9 sample-to-broth ratio. The pre-enriched sample was diluted in broth by a 10 -fold serial dilution $\left(10^{-2}, 10^{-3}\right.$, and $\left.10^{-4}\right)$. Then, $1 \mathrm{~mL}$ of each dilution was pipetted and spread onto the plate count agar (PCA; Merck, Darmstadt, Germany). The agar plates were incubated at $37^{\circ} \mathrm{C}$ for $24 \mathrm{~h}$. The experiments were carried out in triplicate, and the results were expressed as log colony-forming units per gram $(\log \mathrm{CFU} / \mathrm{g})$.

\subsection{Antioxidant Assays}

Extraction was performed before the antioxidant assays. Fresh silkworm, hot water-treated silkworm, and silkworm powder were weighed at $10 \mathrm{~g}$ each (dry weight equivalent) and mixed with $50 \mathrm{~mL}$ of $85 \%(v / v)$ ethanol (Merck, Darmstadt, Germany). The mixture of each sample was left at the ambient temperature for $1 \mathrm{~h}$. The mixture was then filtered using Whatman ${ }^{\circledR}$ Grade 4 filter paper. 


\subsection{Total Phenolic Compounds (TPCS)}

Total phenolic compounds (TPCs) of the silkworms were determined by the Folin-Ciocalteu method with slight modification from Li et al. [26]. Approximately $100 \mu \mathrm{L}$ of silkworm extract was mixed with $2 \mathrm{~mL}$ of $10 \%(v / v)$ Folin-Ciocalteu reagent (Merck, Darmstadt, Germany), and the mixture was left for $3 \mathrm{~min}$ at the ambient temperature. Then, $2.5 \mathrm{~mL}$ of $7.5 \%(w / v)$ sodium carbonate (Sigma, Darmstadt, Germany) was added to the mixture and incubated in the dark for $2 \mathrm{~h}$. Absorbance was recorded using a spectrophotometer (BMG Labtech, Ortenberg, Germany) at $760 \mathrm{~nm}$. Gallic acid was used as the standard for calibration. TPC was expressed in terms of $\mu \mathrm{mol}$ gallic acid equivalents per $1 \mathrm{~g}$ dry weight (DW) sample ( $\mu \mathrm{mol}$ GAE/g of DW sample).

\subsection{The 2,2-Diphenyl-1-picrylhydrazyl (DPPH) Free Radical Scavenging Assay}

The determination of the scavenging activity of the silkworm extracts on the stable free radical DPPH was done as described in Phongthai et al. [27] with slight modification. The DPPH stock solution was prepared by dissolving $40 \mathrm{mg}$ of DPPH (Sigma, Germany) in $100 \mathrm{~mL}$ methanol (Merck, Germany) to yield an absorbance of $0.70 \pm 0.01$ at $517 \mathrm{~nm}$. Silkworm extract $(100 \mu \mathrm{L})$ or blank were mixed with 0.1 $\mathrm{mM}$ of DPPH reagent $(2.9 \mathrm{~mL})$. The mixture was then left in the dark for $30 \mathrm{~min}$ at ambient temperature. The absorbance of the mixture was measured by spectrophotometer (Thermo Spectronic, Model Genesys 10UV-Scanning, CE, Wisconsin, WI, USA) at $517 \mathrm{~nm}$. All samples and controls were done in triplicate. A standard curve was prepared using standard Trolox at concentrations of $0.01-0.40 \mathrm{mg} / \mathrm{mL}$. Ethanol served as negative control (without samples). The values were expressed in terms of $\mu \mathrm{mol}$ equivalent of Trolox/dry basis ( $\mu \mathrm{mol} \mathrm{TE} / \mathrm{g}$ DW).

\subsection{The 2,2'-Azino-bis(3-ethylbenzothiazoline-6-sulfonic Acid (ABTS) Assay}

Antioxidant activities of silkworm extract were determined using the method as described by Phongthai et al. [27] with slight modification. The stock solution was prepared by mixing $7 \mathrm{mM} 2$, 2-azinobis-3-ethyl-benzothiazoline-6-sulfonic acid (ABTS) reagent with $2.45 \mathrm{mM}$ potassium persulfate $\left(\mathrm{K}_{8} \mathrm{~S}_{2} \mathrm{O}_{8}\right)$ at a ratio of 1:1. The mixture was left in the dark for $12 \mathrm{~h}$ at ambient temperature. After $12 \mathrm{~h}$, the mixture was diluted with deionized water until the absorbance at $734 \mathrm{~nm}$ wavelength reached $0.70 \pm 0.05$ using the spectrophotometer. An aliquot of silkworm extract $(150 \mu \mathrm{L})$ was mixed with $2.85 \mathrm{~mL}$ of ABTS radical cation stock solution before $2 \mathrm{~h}$ incubation in the dark. The absorbance of the mixture was measured at $734 \mathrm{~nm}$. Ethanol served as negative control (without samples). The value was expressed in terms of $\mu \mathrm{mol}$ Trolox equivalent/g ( $\mu \mathrm{mol} \mathrm{TE} / \mathrm{g} D W)$.

\subsection{Ferric Reducing Antioxidant Power (FRAP) Assay}

The antioxidant activity of silkworm extract was determined according to Phongthai et al. [27] with some modifications. The stock solution of FRAP reagent was prepared using $300 \mathrm{mM}$ acetate buffer, $\mathrm{pH} 3.6$ ( $3.1 \mathrm{~g}$ sodium acetate trihydrate and $16 \mathrm{~mL}$ glacial acid made up to 1:1 with distilled water), $10 \mathrm{mM} \mathrm{TPTZ} \mathrm{(2,4,6-tris} \mathrm{[2-pyridyl]-s-triazine)} \mathrm{in} 40 \mathrm{mM} \mathrm{HCl}$, and $20 \mathrm{mM} \mathrm{FeCl}_{3} \cdot 6 \mathrm{H}_{2} \mathrm{O}$ in a ratio of 10:1:1. Approximately $0.8 \mathrm{~mL}$ of silkworm extract was added to $4 \mathrm{~mL}$ of FRAP reagent and left at ambient temperature for $10 \mathrm{~min}$. The absorbance was measured at $595 \mathrm{~nm}$ using a spectrophotometer after $10 \mathrm{~min}$. A standard calibration curve of ferrous sulphate $\left(\mathrm{FeSO}_{4}\right)$ was plotted to estimate the activity capacity of samples. Ethanol served as negative control (without samples). The results were reported in terms of $\mu \mathrm{mol} \mathrm{Fe}{ }^{2+} / \mathrm{g}$ dry basis sample.

\subsection{Statistical Analysis}

The results were expressed as the mean \pm standard deviation (SD) of three independent experiments. Statistical comparisons of the results were subjected to one-way ANOVA using SPSS version 20. The differences in antioxidant activity and TPC among the different exposure times to hot water at the 
$p<0.05$ level of significance, and the differences in antioxidant activity and TPC among the different drying temperature at the $p<0.05$ level of significance were analyzed by Duncan's triplicates range test.

\section{Results and Discussion}

\subsection{Physicochemical Properties of FASS}

The physicochemical properties of FASS are shown in Table 1. FASS showed a high lightness with an $L^{*}$ value of $58.11 \pm 0.63$ and $b^{*}$ value of $24.45 \pm 0.98$, indicating that FASS in this study was yellowish. According to Taba and Gogoi [28], fifth instar silkworm exists in three forms, i.e., bluish-white, yellow, and bluish-green. FASS had a length of $33.19 \pm 1.72 \mathrm{~mm}$ and a breadth of $6.97 \pm 0.22 \mathrm{~mm}$. Meanwhile, its weight was $1.04 \pm 0.06 \mathrm{~g}$. The size of FASS in this study was almost similar to the size of fifth instar larvae in the study of Gurjar et al. [29] with a length of $57.86 \pm 7.06 \mathrm{~mm}$ and breadth of $7.15 \pm 0.43 \mathrm{~mm}$.

Table 1. Physicochemical properties, total microorganism count and antioxidant activity of fresh Thai silkworm after silking (FASS).

\begin{tabular}{cc}
\hline Properties & Value \\
\hline Physicochemical Properties & \\
Color L* & $58.11 \pm 0.63$ \\
$\mathrm{a}^{*}$ & $1.14 \pm 0.99$ \\
$\mathrm{~b}^{*}$ & $24.45 \pm 0.98$ \\
Wize (mm) length & $33.19 \pm 1.72$ \\
Width & $6.97 \pm 0.22$ \\
Weight $(\mathrm{g})$ & $1.04 \pm 0.06$ \\
\hline Proximate Analysis & \\
Moisture content $(\%)$ & $75.83 \pm 0.63$ \\
Protein $(\%$ DM basis) & $66.66 \pm 1.23$ \\
Fat (\% DM basis) & $20.64 \pm 2.24$ \\
Ash (\% DM basis) & $1.32 \pm 0.13$ \\
Carbohydrate (\% DM basis) & $2.59 \pm 0.43$ \\
Total Microorganism $($ log CFU/g) & $6.54 \pm 0.13$ \\
\hline Antioxidant Activities & \\
DPPH ( $\mu$ mol TE/g DW) & $11.57 \pm 0.80$ \\
ABTS ( $\mu$ mol TE/g DW) & $32.75 \pm 4.57$ \\
FRAP ( $\mu$ mol of Fe ${ }^{2+} / g$ DW $)$ & $54.28 \pm 2.86$ \\
\hline
\end{tabular}

\subsection{Proximate Analysis}

The results of the proximate analysis are shown in Table 1. Protein has the highest percentage (66.66\% of dry matter (DM)) among the components in silkworms. Karthick Raja et al. [30] reported that the protein content in dried silkworm ranged from 52 to $72 \%$. The high content of protein in silkworm was due to the intake of mulberry leaves. Mulberry leaves are the only food source of the silkworm, and the leaves are reported to have high protein content [31].

Fats are identified as the second-highest percentage of components in silkworms. In this study, FASS contained $20.64 \%$ DM basis of fat content, which falls in the range of $18.9-36 \%$, as reported by Kim et al. [32]. Meanwhile, Chieco et al. [33] mentioned that the silkworm contains essential fatty acids (EFA), mainly in the form of polyunsaturated fatty acids (PUFA). In addition, the silkworms also possess a higher n-3 to n- 6 fatty acid ratio, which differs from other insects.

In this study, FASS exhibited high moisture content (75.83\%), and this may have been due to the sole food source of the silkworm, the mulberry leaves [34]. The ash content of FASS was $1.32 \%$ on a dry matter basis. The ash content indicated the amount of minerals present in the insect. Omotoso [35] reported that the silkworm is rich in minerals such as sodium $(\mathrm{Na})$, potassium $(\mathrm{K})$, calcium $(\mathrm{Ca})$, iron $(\mathrm{Fe})$, magnesium $(\mathrm{Mg})$, and zinc $(\mathrm{Zn})$. In addition, the carbohydrate content was found to have a $2.59 \%$ DM basis in FASS. Carbohydrate is identified as the primary food source in silkworms. 


\subsection{Total Microorganisms}

Table 1 shows that the microorganisms count of the silkworm was $6.54 \log \mathrm{CFU} / \mathrm{g}$. The incidence of a high amount of microorganisms is reasonable because the fresh silkworms were rich in nutrients with high moisture content. Li et al. [36] revealed that microorganisms could be found in the intestine of lepidopteran insects such as silkworm, which play essential roles in promoting growth and development.

\subsection{Antioxidant Activities}

A linear calibration curve of Trolox was obtained with good linearity of correlation coefficient $\left(R^{2}=0.979\right)$ and a linear equation of $\mathrm{y}=185.3 \mathrm{x}+18.97$, which was used as positive control for DPPH scavenging activity. The value of the DPPH assay for FASS was $11.57 \pm 0.80 \mu \mathrm{mol}$ TE/g DW. In the FRAP assay, the antioxidant activity of FASS was determined by the ability of antioxidant compounds in silkworm to reduce $\mathrm{Fe}^{3+}$ to $\mathrm{Fe}^{2+}$ in the FRAP reagent. A linear calibration curve of ferrous sulphate $\left(\mathrm{FeSO}_{4}\right)$ was obtained with good linearity of the correlation coefficient $\left(R^{2}=0.996\right)$ and a linear equation of $y=12.66 x+0.031$, which was used as a positive control for the FRAP assay. The FRAP value of FASS was $54.28 \pm 2.86 \mu \mathrm{mol} \mathrm{Fe} \mathrm{F}^{2+} / \mathrm{g}$ on a dry basis, indicating that the fresh silkworm exhibited a strong ferric ion reducing capacity. A linear calibration curve of Trolox was obtained with good linearity of correlation coefficient $\left(R^{2}=0.982\right)$ and a linear equation of $\mathrm{y}=771.1 \mathrm{x}+9.971$, which was used as a positive control for ABTS scavenging activity. The value of the ABTS assay of FASS in this study was $32.75 \pm 4.57 \mu \mathrm{mol}$ TE/g DW. A higher ABTS radical scavenging capability was observed in FASS compared with DPPH measurement. This could be due to the high protein content in fresh silkworm, as reported by Zheng et al. [37], whereby the ABTS assay was more sensitive in evaluating the radical scavenging activities of amino acids and peptides compared with the DPPH assay.

\subsection{Effect of Hot Water Treatment}

FASS was exposed to $90^{\circ} \mathrm{C}$ water before the process of producing silkworm powder. The exposure of FASS to hot water was to kill them thoroughly and for sterilization purposes. As shown in Figure 1A, the TPC of FASS $(18.21 \pm 1.31 \mu \mathrm{mol} \mathrm{GAE} / \mathrm{g}$ DW) was significantly $(p<0.05)$ higher following $5 \mathrm{~min}$ of exposure compared with the other time points. The values of DPPH free radical scavenging assay $(22.43 \pm 2.85 \mu \mathrm{mol} \mathrm{TE} / \mathrm{g}$ DW), ABTS assay $(35.37 \pm 2.99 \mu \mathrm{mol} \mathrm{TE} / \mathrm{g} \mathrm{DW})$, and FRAP assay $\left(55.26 \pm 4.05 \mu \mathrm{mol}\right.$ of $\left.\mathrm{Fe}^{2+} / \mathrm{g} \mathrm{DW}\right)$ were significantly $(p<0.05)$ higher following $5 \mathrm{~min}$ exposure compared with the other time points (Figure 1B-D). Therefore, the samples exposed to $90^{\circ} \mathrm{C}$ water for 5 min were used for subsequent drying treatment.

The TPC, DPPH free radical scavenging assay, and FRAP assay of FASS showed a significant reduction $(p<0.05)$ when the exposure time was extended to 10, 15, and $20 \mathrm{~min}$. The reduction of TPC indicated the loss of antioxidant compound, and this was due to the large surface area of FASS in contact with water [38]. In addition, cooking in the boiling water had an adverse effect on the polyphenol level, as it could diffuse into the boiling water, resulting in the loss of phenolic compounds [39]. On the other hand, it was interesting to note that TPC and antioxidant activity of FASS were significantly $(p<0.05)$ increased at the $5 \mathrm{~min}$ exposure time and gradually decreased after exposure to hot water for 10, 15, and $20 \mathrm{~min}$. The hot water treatment caused the destruction of cell and sub-cellular components in the silkworms, resulting in the release of potent radical-scavenging antioxidants [40]. Furthermore, a study suggested that the thermal inactivation of oxidative enzymes during the heating process led to the suppressed oxidation by antioxidants [39]. 

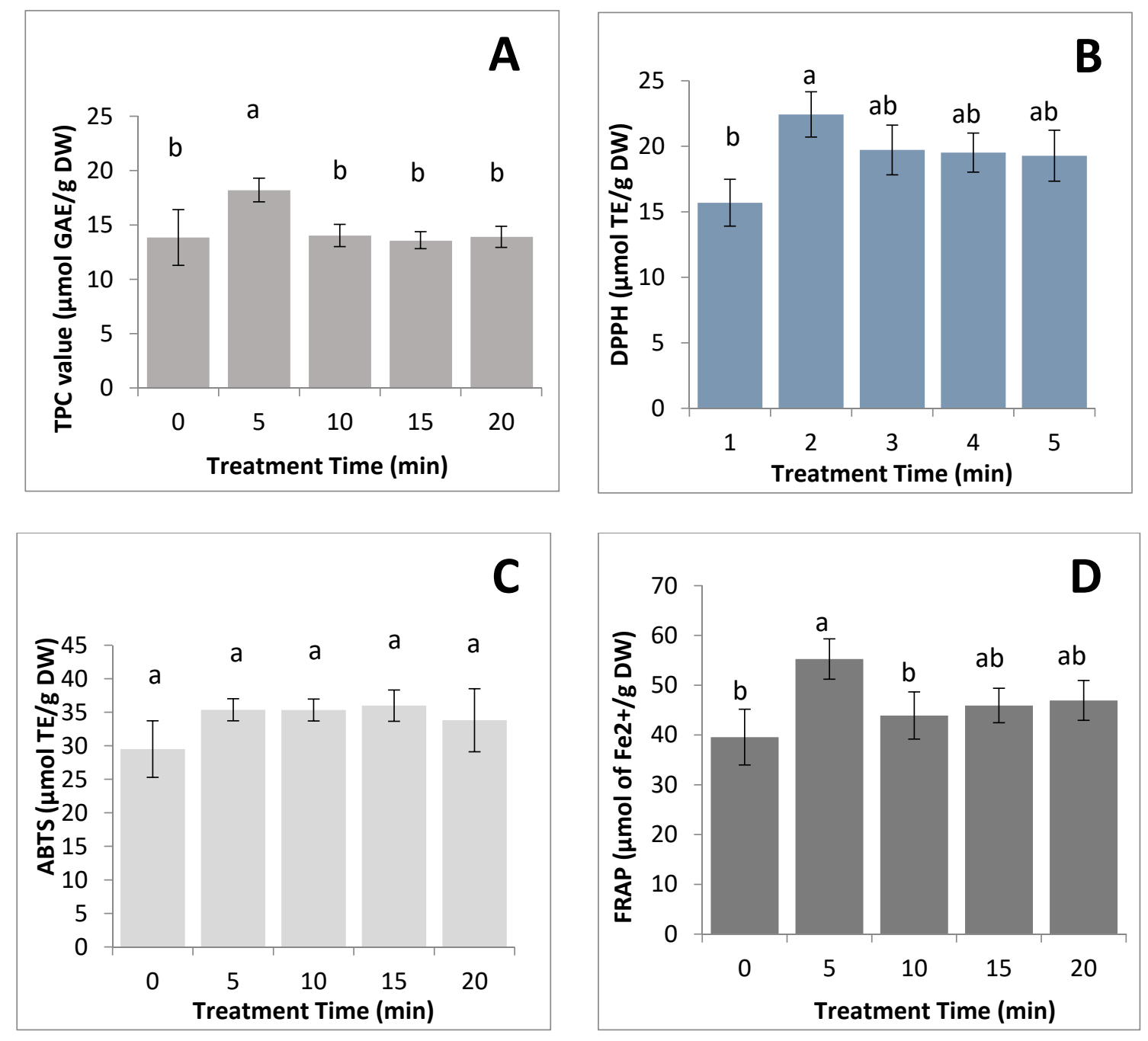

Figure 1. Effect of different treatment time of hot water on antioxidant activity in silkworms. (A) Total phenolic compound (TPC), (B) DPPH free radical scavenging assay, (C) ABTS assay, and (D) ferric reducing antioxidant power (FRAP). The results were expressed as mean $\pm \mathrm{SD}$ of triplicate measurements. The different letter on the bar indicates significantly difference among treatment $(p<0.05)$.

Table 2 shows that the total microorganism load at $0 \mathrm{~min}$ of exposure time was $6.69 \mathrm{log} \mathrm{CFU} / \mathrm{g}$. Following exposure for $5 \mathrm{~min}$, the microorganism count was $1.30 \log \mathrm{CFU} / \mathrm{g}$, while the total microorganism count was less than $1.0 \mathrm{log} \mathrm{CFU} / \mathrm{g}$ for exposure times of 10, 15, and $20 \mathrm{~min}$. It was observed that the reduction in the number of CFU/g was $\geq 3 \log \mathrm{CFU} / \mathrm{g}(99 \%)$. The whole body of the silkworm, including the intestine, was used in the production of silkworm powder. The intestine of silkworm contains a high amount of microorganisms, which affect the quality and shelf life of silkworm powder [41]. Hence, a pre-treatment of the fresh silkworm is an essential step before the production of silkworm powder.

Table 2. Effect of water heat treatment time on total microorganism load in fresh after silking silkworms.

\begin{tabular}{cc}
\hline Treatment Time (min) & Total Microorganisms Load $(\log$ CFU/g) \\
\hline 0 & $6.69 \pm 0.39$ \\
5 & $1.30 \pm 0.38$ \\
10 & $<1$ \\
15 & $<1$ \\
20 & $<1$ \\
\hline
\end{tabular}




\subsection{Effect of Drying Temperature}

The silkworms exposed to $90{ }^{\circ} \mathrm{C}$ water for 5 min were subjected to a hot air dryer. Table 3 shows the effect of different drying temperatures on the physicochemical properties and antioxidant activities of silkworms. For the color measurement of silkworm powder, $\mathrm{L}^{*}$ and $\mathrm{b}^{*}$ values were significantly $(p<0.05)$ decreased when the drying temperature increased. The color fading in the silkworm powder may have been due to the sensitivity of the silkworm color pigment to high temperature [42]. In addition, Dorouzi et al. [43] reported the formation of browning pigments by the non-enzymatic browning or Maillard reactions at high drying temperature, leading to a decrease in lightness. The moisture content of the silkworm powder was measured until the final moisture content was less than $15 \%$, as the growth of microorganism could be prevented when the moisture content was reduced to less than $15 \%[44,45]$.

Table 3. Chemical properties and antioxidant activities of dried silkworms in a hot-air oven at different drying temperatures.

\begin{tabular}{ccccc}
\hline \multirow{2}{*}{ Properties } & \multicolumn{4}{c}{ Drying Temperature $\left({ }^{\circ} \mathbf{C}\right)$} \\
\cline { 2 - 5 } & $\mathbf{8 0}$ & $\mathbf{1 0 0}$ & $\mathbf{1 2 0}$ & $\mathbf{1 4 0}$ \\
\hline Color L $^{*}$ & $47.07^{\mathrm{a}} \pm 0.27$ & $44.80^{\mathrm{c}} \pm 0.24$ & $46.13^{\mathrm{b}} \pm 0.40$ & $44.42^{\mathrm{c}} \pm 0.44$ \\
$\mathrm{a}^{*}$ & $4.68^{\mathrm{c}} \pm 0.10$ & $5.83^{\mathrm{b}} \pm 0.24$ & $6.61^{\mathrm{a}} \pm 0.22$ & $6.67^{\mathrm{a}} \pm 0.08$ \\
$\mathrm{~b}^{*}$ & $17.01^{\mathrm{a}} \pm 0.38$ & $14.36^{\mathrm{c}} \pm 0.68$ & $15.96^{\mathrm{b}} \pm 0.50$ & $13.75^{\mathrm{c}} \pm 0.28$ \\
Moisture content $(\%)$ & $8.08^{\mathrm{a}} \pm 0.37$ & $4.30^{\mathrm{b}} \pm 0.30$ & $2.20^{\mathrm{c}} \pm 0.59$ & $0.70^{\mathrm{d}} \pm 0.18$ \\
Total phenolic compounds $(\mu \mathrm{mol}$ GAE/g DW) & $51.81^{\mathrm{c}} \pm 0.84$ & $47.12^{\mathrm{a}} \pm 0.77$ & $48.96^{\mathrm{ab}} \pm 1.53$ & $50.29^{\mathrm{bc}} \pm 2.12$ \\
\hline Antioxidant Activities & & & & \\
DPPH $(\mu$ mol TE/g DW) & $69.09^{\mathrm{b}} \pm 0.58$ & $68.59^{\mathrm{ab}} \pm 0.31$ & $68.71^{\mathrm{b}} \pm 0.15$ & $67.94^{\mathrm{a}} \pm 0.37$ \\
ABTS $(\mu$ mol TE/g DW) & $69.27^{\mathrm{b}} \pm 2.85$ & $68.90^{\mathrm{b}} \pm 0.56$ & $68.29^{\mathrm{b}} \pm 0.87$ & $57.63^{\mathrm{a}} \pm 0.91$ \\
FRAP $\left(\mu\right.$ mol of Fe ${ }^{2+} / \mathrm{g}$ DW) & $46.73^{\mathrm{b}} \pm 4.54$ & $43.02^{\mathrm{ab}} \pm 2.23$ & $41.71^{\mathrm{ab}} \pm 2.61$ & $39.89^{\mathrm{a}} \pm 2.17$ \\
\hline
\end{tabular}

The results were expressed as mean $\pm \mathrm{SD}(n=3)$ of triplicate measurements. Mean values with the different superscript lowercase letter are significantly different $(p<0.05)$.

The TPC of silkworm powder was significantly $(p<0.05)$ decreased at $100{ }^{\circ} \mathrm{C}$ and increased at 120 and $140{ }^{\circ} \mathrm{C}$. This was due to the release of potent radical-scavenging antioxidants, as reported by Kao et al. [40]. However, the results showed that the TPC of silkworm powder was significantly higher $(51.81 \pm 0.84 \mu \mathrm{mol} \mathrm{GAE} / \mathrm{g} \mathrm{DW})$ at a low drying temperature $\left(80^{\circ} \mathrm{C}\right)$. The DPPH free radical scavenging assay showed a significant $(p<0.05)$ decease as the drying temperature increased and the highest value of DPPH free radical scavenging $(69.09 \pm 0.58 \mu \mathrm{mol} \mathrm{TE} / \mathrm{g} \mathrm{DW})$ was obtained at $80^{\circ} \mathrm{C}$. The results of ABTS and FRAP assays showed a significant $(p<0.05)$ reduction in silkworm powder as the drying temperature increased. In the ABTS assay, silkworm powder possessed the highest ABTS radical scavenging capability $(69.27 \pm 2.85 \mu \mathrm{mol} \mathrm{TE} / \mathrm{g}$ DW $)$ of antioxidant at $80^{\circ} \mathrm{C}$. The FRAP assay of silkworm powder showed a significantly $(p<0.05)$ higher value at $80^{\circ} \mathrm{C}$ compared with the other drying temperatures. The decreased antioxidant activity upon exposure to high temperature was associated with the degradation of antioxidant compounds [46]. Furthermore, the decrease in antioxidant activity in silkworm powder was due to the formation of pro-oxidants by the Maillard reaction when exposed to high temperature [47].

The presence of antioxidant activity in fifth instar silkworms is probably because of the production of sericin. Silkworms produce large quantity of sericin at the fifth instar stage larvae. Sericin was reported to have high antioxidant properties [48]. The high consumption of mulberry leaves during late larval stage contributes to the antioxidant activity, as mulberry leaves have been identified to contain large quantities of phenolic compounds such as flavonoid and its derivatives [49]. Thermal processing, especially water heat treatment, may cause the loss of phenolic compounds, as reports showed that phenolic are highly soluble in water. Phenolics may be lost by leaching. The high temperature may destroy the cell wall and other subcellular compartments, thus facilitates the release of the compound into the water [50]. The reduction of antioxidant compounds may due to certain factors such as temperature, air velocity, heat exposure time, and the content of antioxidant compound [51]. 


\section{Conclusions}

Silkworm and silkworm powder contain antioxidant activities. The results showed that thermal processing could affect the antioxidant activity and some physicochemical properties during the production of silkworm powder. Shorter exposure time to hot water and a lower drying temperature should be applied to prevent the loss of bioactive compounds in silkworm powder. Silkworm powder could be a potential protein source for animal products, and the application may lead to valuable findings in various fields such as pharmaceutical and cosmetic industries.

Author Contributions: A.A. and S.J. developed the study design. A.A. performed the experiments. A.A. and Y.Y.L. interpreted the data, drafted the manuscript, and revised the manuscript. S.J., S.J.L., and W.A.W.M. supervised the project and checked on the manuscript. All authors read and approved the final version of the manuscript.

Funding: This research received no external funding.

Acknowledgments: This research was funded by the Dana Modal Insan (MI-2020-007) research grant provided by Universiti Kebangsaan Malaysia, Tech Enterprise Service Network of Ministry of Science and Technology, Thailand and private grant from NTGS Co. Ltd., Thailand.

Conflicts of Interest: The authors declare no conflict of interest.

\section{References}

1. Barsics, F.; Megido, R.C.; Brostaux, Y.; Barsics, C.; Blecker, C.; Haubruge, E.; Francis, F. Could new information influence attitudes to foods supplemented with edible insects? Br. Food J. 2017, 119, 2027-2039. [CrossRef]

2. Meyer-Rochow, V.B. Can insects help to ease the problem of world food shortage. Search 1975, 6, $261-262$.

3. Ghosh, S.; Jung, C.; Meyer-Rochow, V.B. What governs selection and acceptance of edible insect species? In Edible Insects in Sustainable Food Systems; Springer: Berlin/Heidelberg, Germany, 2018; pp. 331-351.

4. Dong, H.-L.; Zhang, S.-X.; Tao, H.; Chen, Z.-H.; Li, X.; Qiu, J.-F.; Cui, W.-Z.; Sima, Y.-H.; Cui, W.-Z.; Xu, S.-Q. Metabolomics differences between silkworms (Bombyx mori) reared on fresh mulberry (Morus) leaves or artificial diets. Sci. Rep. 2017, 7, 1-16. [CrossRef] [PubMed]

5. Meyer-Rochow, V.B. Therapeutic arthropods and other, largely terrestrial, folk-medicinally important invertebrates: A comparative survey and review. J. Ethnobiol. Ethnomed. 2017, 13, 9. [CrossRef]

6. Butkhup, L.; Jeenphakdee, M.; Jorjong, S.; Samappito, S.; Samappito, W.; Butimal, J. Phenolic composition and antioxidant activity of Thai and Eri silk sericins. Food Sci. Biotechnol. 2012, 21, 389-398. [CrossRef]

7. Tamura, Y.; Nakajima, K.-I.; Nagayasu, K.-I.; Takabayashi, C. Flavonoid 5-glucosides from the cocoon shell of the silkworm, Bombyx Mori. Phytochemistry 2002, 59, 275-278. [CrossRef]

8. Tabunoki, H.; Higurashi, S.; Ninagi, O.; Fujii, H.; Banno, Y.; Nozaki, M.; Kitajima, M.; Miura, N.; Atsumi, S.; Tsuchida, K. A carotenoid-binding protein (CBP) plays a crucial role in cocoon pigmentation of silkworm (Bombyx mori) larvae. FEBS Lett. 2004, 567, 175-178. [CrossRef]

9. Tao, M.; Wang, C.; Liao, D.; Liu, H.; Zhao, Z.; Zhao, Z. Purification, modification and inhibition mechanism of angiotensin I-converting enzyme inhibitory peptide from silkworm pupa (Bombyx mori) protein hydrolysate. Process. Biochem. 2017, 54, 172-179. [CrossRef]

10. Zhao, P.; Xia, F.; Jiang, L.; Guo, H.; Xu, G.; Sun, Q.; Wang, B.; Wang, Y.; Lu, Z.; Xia, Q. Enhanced antiviral immunity against Bombyx mori cytoplasmic polyhedrosis virus via overexpression of peptidoglycan recognition protein S2 in transgenic silkworms. Dev. Comp. Immunol. 2018, 87, 84-89. [CrossRef]

11. Rattana, S.; Katisart, T.; Sungthong, B.; Butiman, C. Acute and sub-acute toxicities of Thai Silkworm Powder (Bombyx mori Linn.) from three races in male Wistar rats and in vitro antioxidant activities. Pharmacogn. J. 2017, 9, 541-545. [CrossRef]

12. Xu, S.; Wang, F.; Wang, Y.; Wang, R.; Hou, K.; Tian, C.; Ji, Y.; Yang, Q.; Zhao, P.; Xia, Q. A silkworm based silk gland bioreactor for high-efficiency production of recombinant human lactoferrin with antibacterial and anti-inflammatory activities. J. Biol. Eng. 2019, 13, 61. [CrossRef] [PubMed]

13. Dutta, P.; Dey, T.; Manna, P.; Kalita, J. Antioxidant potential of Vespa affinis L., a traditional edible insect species of North East India. PLoS ONE 2016, 11, e0156107. [CrossRef] [PubMed]

14. Dutta, P.; Dey, T.; Dihingia, A.; Manna, P.; Kalita, J. Antioxidant and glucose metabolizing potential of edible insect, Brachytrupes orientalis via modulating Nrf2/AMPK/GLUT4 signaling pathway. Biomed. Pharmacother. 2017, 95, 556-563. [CrossRef] [PubMed] 
15. Lee, J.H.; Kim, S.; Jo, Y.-Y.; Kweon, H.; Jeon, J.Y.; Ju, W.-T.; Kim, H.-B.; Kim, K.-Y.; Kim, S.-W.; Kim, S.-B. Effect of humidity on the quality characteristics of the $3 \mathrm{rd}$ day of 5 th instar silkworm powder. Int. J. Ind. Entomol. 2019, 39, 74-81.

16. Suk, W.; Kim, J.; Kim, D.-Y.; Lim, H.; Choue, R. Effect of Wheat Flour Noodles with Bombyx mori Powder on Glycemic Response in Healthy Subjects. Prev. Nutr. Food Sci. 2016, 21, 165. [CrossRef]

17. Park, Y.-S.; Choi, Y.-S.; Hwang, K.-E.; Kim, T.-K.; Lee, C.-W.; Shin, D.-M.; Han, S.G. Physicochemical properties of meat batter added with edible silkworm pupae (Bombyx mori) and transglutaminase. Korean J. Food Sci. Anim. Resour. 2017, 37, 351. [CrossRef]

18. Biró, B.; Fodor, R.; Szedljak, I.; Pásztor-Huszár, K.; Gere, A. Buckwheat-pasta enriched with silkworm powder: Technological analysis and sensory evaluation. LWT 2019, 116, 108542. [CrossRef]

19. Hashim, M.A.; Yahya, F.; Mustapha, W.A.W. Effect of different drying methods on the morphological structure, colour profile and citral concentration of Lemongrass (Cymbopogon citratus) powder. Asian J. Agric. Biol. 2019, 7, 93-102.

20. Nur Tantiyani, A.O.; Razalib, M.E.F.M. Drying of Instant Coffee in a Spray Dryer. J. Kejuruter. 2019, 31, 295-301.

21. Baek, M.; Yoon, Y.-I.; Kim, M.; Hwang, J.-S.; Goo, T.-W.; Yun, E.-Y. Physical and sensory evaluation of Tenebrio molitor larvae cooked by various cooking methods. Korean J. Food Cook. Sci. 2015, 31, 534-543. [CrossRef]

22. Jensen, A.B.; Evans, J.; Jonas-Levi, A.; Benjamin, O.; Martinez, I.; Dahle, B.; Roos, N.; Lecocq, A.; Foley, K. Standard methods for Apis mellifera brood as human food. J. Apic. Res. 2019, 58, 1-28. [CrossRef]

23. Hashim, H.; Embong, F.A.; Yee, C.K.; Daud, N.M.; Rahman, H.A. Effect of different drying methods and ethanol concentrations on antioxidant and anti-hyperglycaemic properties of gynura procumbens leaves extract. Malays. Appl. Biol. 2018, 47, 157-164.

24. Norafida, A.; Aminah, A. Effect of blanching treatments on antioxidant activity of frozen green Capsicum (Capsicum annuum L. var bell pepper). Int. Food Res. J. 2018, 25, 1427-1434.

25. Maturin, L.; Peeler, J. BAM aerobic plate count. In Bacteriological Analytical Manual; US Food and Drug Administration: Silver Spring, MD, USA, 2001.

26. Li, H.-B.; Cheng, K.-W.; Wong, C.-C.; Fan, K.-W.; Chen, F.; Jiang, Y. Evaluation of antioxidant capacity and total phenolic content of different fractions of selected microalgae. Food Chem. 2007, 102, 771-776. [CrossRef]

27. Phongthai, S.; D'Amico, S.; Schoenlechner, R.; Homthawornchoo, W.; Rawdkuen, S. Fractionation and antioxidant properties of rice bran protein hydrolysates stimulated by in vitro gastrointestinal digestion. Food Chem. 2018, 240, 156-164. [CrossRef]

28. Taba, M.; Gogoi, H. Report on Wild Eri Silkworm Samia canningii Hutton (Lepidoptera: Saturniidae) from Arunachal Pradesh, India. Natl. Acad. Sci. Lett. 2019, 42, 147-150. [CrossRef]

29. Gurjar, T.S.; Siddhapara, M.R.; Surani, P.M. Biology of mulberry silkworm, Bombyx mori L. on mulberry, Morus alba L. J. Entomol. 2018, 6, 276-280.

30. Karthick Raja, P.; Aanand, S.; Stephen Sampathkumar, J.; Padmavathy, P. Silkworm pupae meal as alternative source of protein in fish feed. J. Entomol. Zool. Stud. 2019, 7, 78-85.

31. Yu, Y.; Li, H.; Zhang, B.; Wang, J.; Shi, X.; Huang, J.; Yang, J.; Zhang, Y.; Deng, Z. Nutritional and functional components of mulberry leaves from different varieties: Evaluation of their potential as food materials. Int. J. Food Prop. 2018, 21, 1495-1507. [CrossRef]

32. Kim, H.-W.; Setyabrata, D.; Lee, Y.J.; Jones, O.G.; Kim, Y.H.B. Pre-treated mealworm larvae and silkworm pupae as a novel protein ingredient in emulsion sausages. Innov. Food Sci. Emerg. Technol. 2016, 38, 116-123. [CrossRef]

33. Chieco, C.; Morrone, L.; Bertazza, G.; Cappellozza, S.; Saviane, A.; Gai, F.; Di Virgilio, N.; Rossi, F. The Effect of Strain and Rearing Medium on the Chemical Composition, Fatty Acid Profile and Carotenoid Content in Silkworm (Bombyx mori) Pupae. Animals 2019, 9, 103. [CrossRef] [PubMed]

34. Rahmathulla, V.; Tilak, R.; Rajan, R. Influence of moisture content of mulberry leaf on growth and silk production in Bombyx mori L. Caspian J. Environ. Sci. 2006, 4, 25-30.

35. Omotoso, O.T. An Evaluation of the Nutrients and Some Anti-nutrients in Silkworm, Bombyx mori L. (Bombycidae: Lepidoptera). Jordan J. Biol. Sci. 2015, 8, 45-50. [CrossRef]

36. Li, M.; Li, F.; Lu, Z.; Fang, Y.; Qu, J.; Mao, T.; Wang, H.; Chen, J.; Li, B. Effects of $\mathrm{TiO}_{2}$ nanoparticles on intestinal microbial composition of silkworm. Bombyx Mori. Sci. Total Environ. 2020, 704, 135273. [CrossRef] [PubMed] 
37. Zheng, L.; Lin, L.; Su, G.; Zhao, Q.; Zhao, M. Pitfalls of using 1, 1-diphenyl-2-picrylhydrazyl (DPPH) assay to assess the radical scavenging activity of peptides: Its susceptibility to interference and low reactivity towards peptides. Food Res. Int. 2015, 76, 359-365. [CrossRef]

38. Chuah, A.M.; Lee, Y.-C.; Yamaguchi, T.; Takamura, H.; Yin, L.-J.; Matoba, T. Effect of cooking on the antioxidant properties of coloured peppers. Food Chem. 2008, 111, 20-28. [CrossRef]

39. Gunathilake, K.; Ranaweera, K.; Rupasinghe, H. Effect of different cooking methods on polyphenols, carotenoids and antioxidant activities of selected edible leaves. Antioxidants 2018, 7, 117. [CrossRef]

40. Kao, F.-J.; Chiu, Y.-S.; Chiang, W.-D. Effect of water cooking on antioxidant capacity of carotenoid-rich vegetables in Taiwan. J. Food Drug Anal. 2014, 22, 202-209. [CrossRef]

41. Garofalo, C.; Osimani, A.; Milanović, V.; Taccari, M.; Cardinali, F.; Aquilanti, L.; Riolo, P.; Ruschioni, S.; Isidoro, N.; Clementi, F. The microbiota of marketed processed edible insects as revealed by high-throughput sequencing. Food Microbiol. 2017, 62, 15-22. [CrossRef]

42. Ma, M.; Hussain, M.; Dong, S.; Zhou, W. Characterization of the pigment in naturally yellow-colored domestic silk. Dyes Pigment. 2016, 124, 6-11. [CrossRef]

43. Dorouzi, M.; Mortezapour, H.; Akhavan, H.-R.; Moghaddam, A.G. Tomato slices drying in a liquid desiccant-assisted solar dryer coupled with a photovoltaic-thermal regeneration system. Solar Energy 2018, 162, 364-371. [CrossRef]

44. Mujuru, F.M.; Kwiri, R.; Nyambi, C.; Winini, C.; Moyo, D.N. Microbiological quality of Gonimbrasia belina processed under different traditional practices in Gwanda, Zimbabwe. Int. J. Curr. Microbiol. Appl. Sci. 2014, 3, 1085-1094.

45. Ho, L.-H.; Ramli, N.F.; Tan, T.-C.; Muhamad, N.; Haron, M.N. Effect of extraction solvents and drying conditions on total phenolic content and antioxidant properties of watermelon rind powder. Sains Malays. 2018, 47, 99-107. [CrossRef]

46. Correia, P.; Guiné, R.P.; Correia, A.C.; Gonçalves, F.; Brito, M.; Ribeiro, J. Physical, chemical and sensorial properties of kiwi as influenced by drying conditions. Agric. Eng. Int. CIGR J. 2017, 19, 203-212.

47. De Carvalho Tavares, I.M.; de Castilhos, M.B.M.; Mauro, M.A.; Ramos, A.M.; de Souza, R.T.; Gómez-Alonso, S.; Gomes, E.; Da-Silva, R.; Hermosín-Gutiérrez, I.; Lago-Vanzela, E.S. BRS Violeta (BRS Rúbea× IAC 1398-21) grape juice powder produced by foam mat drying. Part I: Effect of drying temperature on phenolic compounds and antioxidant activity. Food Chem. 2019, 298, 124971. [CrossRef] [PubMed]

48. Kunz, R.I.; Brancalhão, R.M.C.; Ribeiro, L.D.F.C.; Natali, M.R.M. Silkworm sericin: Properties and biomedical applications. BioMed Res. Int. 2016, 2016, 1-19. [CrossRef]

49. Taufik, Y.; Widiantara, T.; Garnida, Y. The effect of drying temperature on the antioxidant activity of black mulberry leaf tea (Morus nigra). Rasayan J. Chem. 2016, 9, 889-895.

50. Minatel, I.O.; Borges, C.V.; Ferreira, M.I.; Gomez, H.A.G.; Chen, C.-Y.O.; Lima, G.P.P. Phenolic compounds: Functional properties, impact of processing and bioavailability. In Phenolic Compounds Biological Activity; InTech: Rijeka, Croatia, 2017; pp. 1-24.

51. Vega-Gálvez, A.; Ah-Hen, K.; Chacana, M.; Vergara, J.; Martínez-Monzó, J.; García-Segovia, P.; Lemus-Mondaca, R.; Di Scala, K. Effect of temperature and air velocity on drying kinetics, antioxidant capacity, total phenolic content, colour, texture and microstructure of apple (var. Granny Smith) slices. Food Chem. 2012, 132, 51-59.

(C) 2020 by the authors. Licensee MDPI, Basel, Switzerland. This article is an open access article distributed under the terms and conditions of the Creative Commons Attribution (CC BY) license (http://creativecommons.org/licenses/by/4.0/). 